\title{
2D Kinetic Analysis of TCR and CD8 Coreceptor for LCMV GP33 Epitopes
}

\author{
Elizabeth M. Kolawole ${ }^{1}$, Rakieb Andargachew ${ }^{2}$, Baoyu Liu ${ }^{1}$, Jesica R. Jacobs ${ }^{1}$ and \\ Brian D. Evavold ${ }^{1 *}$
}

${ }^{1}$ Department of Pathology, Microbiology and Immunology, University of Utah, Salt Lake City, UT, United States, ${ }^{2}$ Department of Microbiology and Immunology, Emory University, Atlanta, GA, United States

\section{OPEN ACCESS}

Edited by:

Jorge Bernardino De La Serna,

United Kingdom Research and

Innovation, United Kingdom

Reviewed by:

Philip Anton Van Der Merwe, University of Oxford, United Kingdom Johannes Huppa,

Medizinische Universität Wien, Austria

*Correspondence:

Brian D. Evavold

brian.evavold@path.utah.edu

Specialty section:

This article was submitted to

T Cell Biology,

a section of the journal

Frontiers in Immunology

Received: 18 June 2018 Accepted: 21 September 2018

Published: 15 October 2018

Citation: Kolawole EM, Andargachew R, Liu B, Jacobs JR and Evavold BD (2018) $2 D$ Kinetic Analysis of TCR and CD8 Coreceptor for LCMV GP33 Epitopes.

Front. Immunol. 9:2348.

doi: 10.3389/fimmu.2018.02348
The LCMV GP33 CD8 epitope has long been one of the most widely used antigens in viral immunology. Of note, almost all of the in vitro analyses of CD8 T cell responses to this epitope make use of an altered peptide ligand (APL) in which the cysteine from the original 9-mer peptide (KAVYNFATC) is substituted by a methionine at position 41 (KAVYNFATM). In addition, it is possible that the antigen processed during natural LCMV infection is an 11-mer peptide (KAVYNFATCGI) rather than the widely used 9-mer. Although previous affinity measurements using purified proteins for these antigen variants revealed minimal differences, we applied highly sensitive two dimensional (2D) biophysical based techniques to further dissect TCR interaction with these closely related GP33 variants. The kinetic analyses of affinity provided by the 2D micropipette adhesion frequency assay (2D-MP) and bond lifetime under force analyzed using a biomembrane force probe (BFP) revealed significant differences between $41 \mathrm{M}, 41 \mathrm{C}$ and the 11-mer 41CGI antigen. We found a hierarchy in 2D affinity as $41 \mathrm{M}$ peptide displayed augmented TCR 2D affinity compared to $41 \mathrm{C}$ and $41 \mathrm{CG}$. These differences were also maintained in the presence of CD8 coreceptor and when analysis of total TCR:pMHC and CD8:pMHC bonds were considered. Moreover, the three ligands displayed dramatic differences in the bond lifetimes generated under force, in particular the 41CGI variant with the lowest 2D affinity demonstrated a 15-fold synergistic contribution of the CD8 coreceptor to overall bond lifetime. Our analyses emphasize the sensitivity of single cell and single bond 2D kinetic measurements in distinguishing between related agonist peptides.

Keywords: TCR:pMHC, affinity, catch bond, GP33, LCMV, super agonist, immunodominance, CD8 T cell

\section{INTRODUCTION}

CD8+ cytotoxic T lymphocytes (CTLs), which recognize peptides presented by major histocompatibility complex (MHC) class I molecules, are critical for the antigen specific clearance of viral infections $(1,2)$. All CTL responses are dependent on recognition of the viral peptide, followed by sufficient triggering of the TCR to induce a cascade of signaling events (3). Thus, the initial interactions of TCR with pMHC are central to the recruitment of the adaptive immune arm of T cell mediated immunity. Consequently, the affinity of TCR for pMHC and other proximal parameters such as macromolecular orientation $(4,5)$, mechanosensing $(6,7)$, stability of the TCR:pMHC complex $(8,9)$, bond lifetime under force $(9-11)$ and segregation of phosphatases from the T cell:APC synapse $(9,12-15)$ are critical in determining the efficiency of T cell differentiation and effector functions. 
A major question that persists is how $\mathrm{T}$ cells can simultaneously possess a high level of specificity coupled with extreme sensitivity for as few as a single pMHC molecule $(16,17)$. This question has led to a number of models and technologies seeking to explain how TCR recognition of various pMHC complexes leads to such functionally different outcomes, giving rise to agonists and antagonist classifications (18-20). Affinity and $\mathrm{T}$ cell kinetics of TCR:pMHC can be acquired by surface plasmon resonance (SPR) which measures the receptor:ligand interaction in three dimensions (3D) (21), but this method lacks the sensitivity to measure the entire gamut of pMHC ligands, especially the lower affinity interactions. In contrast to using purified proteins for $3 \mathrm{D}$ measurements where the receptor:ligand interaction is isolated from cells, 2D based measures incorporate the proteins into the cellular membrane and are assessed at the cell-cell junctions, providing an added biological component to the interactions. More importantly, the $2 \mathrm{D}$ measurements possess increased levels of sensitivity to measure lower affinity and shorter bond lifetime interactions $(6,22,23)$.

Lymphocytic choriomeningitis virus (LCMV) is one of the best characterized viral model systems in mice (24-26). LCMV has been key in impacting our overall understanding of $\mathrm{T}$ cell immunology responsible for many seminal findings including, but not limited to: peptide:MHC restriction, the kinetics of primary and memory $\mathrm{T}$ cell responses, viral epitope escape, $\mathrm{T}$ cell exhaustion and the role of PD-1, (27-30). An important feature is the existence of several well characterized strains conferring either a chronic (Clone 13 strain) or acute (Armstrong strain) viral infection $(25,31)$. During the response to LCMV infection, the majority of CD8+ CTLs are directed against three viral immunodominant $\mathrm{H}-2 \mathrm{D}^{\mathrm{b}}$ MHC class I epitopes (in C57BL/6 mice); $\mathrm{GP}_{33-41}, \mathrm{GP}_{276-286}$, and $\mathrm{NP}_{396-404}(32,33)$. Both the 11-mer $\mathrm{GP}_{276-286}$ and the 9-mer $\mathrm{NP}_{396-404}$ have a single optimal sequence. However, GP33 has been analyzed using several epitopes: the 9-mer $41 \mathrm{M}, \mathrm{GP}_{33-41}$ (KAVYNFATC) (41C) and the 11 amino acid long $\mathrm{GP}_{33-43}$ (KAVYNFATCGI) (41CGI) (8).

The altered peptide ligand (APL) 9-mer 41M, was created by introducing a single methionine at the carboxy terminal end replacing the cysteine at position $41,(27,34,35)$. The terminal cysteine has been shown to form peptide dimers and has decreased stability in the MHC $(27,34-36)$. These data showed an increase in MHC class I binding from $41 \mathrm{C}$ to $41 \mathrm{M}$ (37). Therefore, most analyses of the LCMV GP33 $\mathrm{D}^{\mathrm{b}}$ response have been analyzed with the more stable APL. Because of these changes in the peptide antigen used for the LCMV response, we sought to determine how the three immunodominant GP33 epitopes alter the $2 \mathrm{D}$ kinetics of TCR recognition of the respective antigens and the CD8 $\mathrm{T}$ cell functional response. In addition to the TCR:pMHC interaction we wanted to investigate the contribution of CD8 coreceptor to the TCR signaling. When blocked or in the absence of CD8 coreceptor, CD8+ T cells require longer and more substantial TCR engagement $(38,39)$. It has been suggested that CD8 binding helps weak ligands with low TCR:pMHC affinities (40). Furthermore, it has been demonstrated that CD8 binds sequentially following TCR:pMHC engagement (41). Here, we demonstrate the distinct hierarchy of $2 \mathrm{D}$ kinetics for the three viral variants that has been absent in 3D kinetic analyses. In addition, we found the contribution of CD8 coreceptor to bond lifetime under force strikingly increases with the weaker 41CGI variant. Our work demonstrates that 2D analysis can sensitively distinguish differences in closely related agonist peptides.

\section{MATERIALS AND METHODS}

\section{Mice}

C57BL/6 (B6) mice were purchased from the National Cancer Institute (NCI) and Charles River. P14 (Thy 1.2) TCR transgenic mice were housed and bred at the University of Utah. All animal experiments were conducted with the approval of the Institutional Animal Care and Use Committee at the University of Utah. C57BL6 Thy 1.1 congenic mice used as hosts for adoptive transfers were purchased from NCI. All mice were between 8 and 12 weeks of age.

\section{Virus}

Lymphocytic choriomeningitis virus (LCMV) Armstrong were kindly provided by Dr. Matthew Williams (University of Utah) and was made as described (42).

\section{Peptides}

GP33-41M (KAVYNFATM), GP33-41C (KAVYNFATC) and cognate GP33-43 (KAVYNFATCGI) peptides were synthesized at the University of Utah on the Prelude X peptide synthesizer (Protein Technologies).

\section{Adoptive Cell Transfer}

Naïve CD8 + T cells were isolated from spleens of P14 (Thy 1.2) transgenic mice using MACS CD8 $+\mathrm{T}$ cell magnetic separation kit (Miltenyi Biotec) and intravenously transferred to congenic C57BL/6 (Thy1.1) hosts. Mice were infected with $2 \times 10^{5} \mathrm{PFU}$ of Armstrong by intraperitoneal (i.p.) injection $24 \mathrm{~h}$ after adoptive cell transfer.

\section{LCMV INFECTIONS}

8-12 weeks old C57BL/6 mice were injected i.p. with $2 \times$ $10^{5} \mathrm{pfu}$ Armstrong and sacrificed at 8 days post infection. Spleens were harvested and stimulated with either KAVYNFATM (41M), KAVYNFATC (41C) or KAVYNFATCGI (41CGI) for $1 \mathrm{~h}$ and then intracellular cytokine staining was performed.

\section{D MICROPIPETTE ADHESION FREQUENCY ASSAY (2D-MP)}

The relative 2D affinity of naïve $\mathrm{P} 14 \mathrm{H} 2 \mathrm{D}^{\mathrm{b}}$ GP33 specific CD8+ $\mathrm{T}$ cells was measured using the previously characterized 2D-MP (6, 43-47). In brief, RBC's were coated with Biotin-LC-NHS (BioVision) followed by streptavidin (Thermo Fisher Scientific) and either biotinylated pMHC $\mathrm{GP}_{33-41 \mathrm{M}}$ (KAVYNFATM), $\mathrm{GP}_{33-41 \mathrm{C}}$ (KAVYNFATC) or $\mathrm{GP}_{33-43}$ (KAVYNFATCGI) monomers. For relative 2D affinity measurements of TCR:pMHC 
interaction, monomers with the $\mathrm{D}^{\mathrm{b}} \mathrm{D} 227 \mathrm{~K}$ mutation were used abrogating CD8 binding to MHC or without the $\mathrm{D}^{\mathrm{b}} \mathrm{D} 227 \mathrm{~K}$ mutation measuring normalized adhesion bonds of the TCR:pMHC:CD8 trimolecular interaction. All monomers were obtained from the NIH Tetramer Core Facility. In both sets of experiments the adhesion frequency between a single $\mathrm{T}$ cell and a ligand coated RBC aspirated on opposing pipettes was observed using an inverted microscope. An electronically controlled piezoelectric actuator repeated a $\mathrm{T}$ cell contact and separation cycle with the pMHC coated RBC 50 times while keeping contact area $\left(\mathrm{A}_{\mathrm{c}}\right)$ and time $(\mathrm{t})$ constant. Upon retraction of the T cell, adhesion (binding of TCR:pMHC) was observed as a distention of the RBC membrane, allowing for quantification of the adhesion frequency $(\mathrm{Pa})$ at equilibrium. Surface pMHC $\left(\mathrm{m}_{\mathrm{l}}\right)$ and TCR $\left(\mathrm{m}_{\mathrm{r}}\right)$ densities were determined by flow cytometry using an anti-TCR $\beta$ PE antibody (H57-597; BD Biosciences) and an anti-H2D ${ }^{\mathrm{b}}$ antibody (clone:28-14-8; eBioscience) both at saturating concentrations along with BD QuantiBRITE PE beads for standardization (BD Biosciences). The calculation of molecules per area was determined by dividing the number of TCR and pMHC per cell by the respective surface areas. The relative $2 \mathrm{D}$ affinities were calculated using the following equation: $\mathrm{A}_{\mathrm{c}} \mathrm{K}_{\mathrm{a}}=-\ln \left[1-\mathrm{P}_{\mathrm{a}}(1)\right] / \mathrm{m}_{\mathrm{r}} \mathrm{m}_{\mathrm{l}}$. Normalized adhesion frequency was calculated using the equation $\left[-\ln (1-\mathrm{Pa}(\mathrm{s})) / \mathrm{m}_{1}\right.$ (pMHC)]. Geometric means of all measured single cell affinities and normalized adhesion bonds are reported \pm SEM. The centerpiece of our micropipette system is an Olympus IX71 inverted microscope equipped with fluorescence and a 100X oil immersion phase contrast and suspended on a TMC CleanBench vibration isolation table. The micropipettes are mounted onto the stage by adapters made by Narishige and are controlled by both fine and coarse micromanipulators. One micropipette is attached to the piezoelectric actuator via a Physik Instrumente P-840.1 piezo amplifier control module that is controlled by LabVIEW software on the imaging workstation. Micropipettes are held by Narishige HI-7 injection holders affixed by the heads of Narishige UT-2 universal joints (with joint removed) on custom mounts. Aspiration pressure of the micropipettes is maintained by Kontes water columns on height adjustable Velmex Unislide height adjusters. Micropipettes are produced on a Sutter Instruments P-1,000 pipette puller and finished using a Narishige MF-900 microforge.

\section{Biomembrane Force Probe Assay (BFP)}

Bond lifetime measurements under force were captured using the biomembrane force probe Assay (BFP). Procedures for coupling pMHC to glass beads have been described previously $(10,48)$. In brief, RBCs were first biotinylated with EZ-link NHS-PEG-Biotin (Thermo Fisher Scientific) and then reacted to streptavidin. Borosilicate beads were first cleaned, silanized, and then reacted to streptavidin-maleimide (Sigma-Aldrich, St. Louis, MO). Streptavidin beads were then coated with biotinylated pMHC either $\mathrm{GP}_{33-41 \mathrm{M}}$ (KAVYNFATM), GP $33-41 \mathrm{C}$ (KAVYNFATC) or $\mathrm{GP}_{33-43}$ (KAVYNFATCGI) monomers and placed on the apex of an RBC that was aspirated onto a micropipette. This bead served as a force probe. The position of the edge of the bead was tracked by a high-resolution camera (1,600 frames/s) with
$<3 \mathrm{~nm}$ displacement precision. The T cell of interest was brought into contact with the glass bead, then retracted a set distance and held by the computer-controlled piezoelectric actuator. The retraction and hold-phase generated a force on the TCR:pMHC bond, which can be altered based on the distance the $\mathrm{T}$ cell is retracted. The camera then recorded the time it took for the $\mathrm{T}$ cell to disengage the glass bead, which was visualized as the $\mathrm{RBC}$ retracted and the bead returned to its starting position. Repeated cycles (known as force-clamp cycles) can be carried out at a single force in order to generate an average bond lifetime between the TCR and pMHC complex. For an optimal response to antigen, the bond lifetime increases with increasing force before reaching a peak bond lifetime, which is typical of a catch bond physiology. By varying the force and measuring the bond lifetimes one can determine what type of bond occurred. Bond lifetimes were analyzed as described (47) using a customized package run by LabVIEW (National instruments) first described by Chen et al. (49). The BFP is built around a Carl Zeiss Axio Observer A1 inverted microscope with two Narishige three-axis hanging joystick oil micromanipulators that allow for precise control of the micropipettes. One micropipette is attached to a Physik Instrumente piezoelectric actuator with nanometer resolution that is controlled with software programed on LabVIEW. To aspirate cells onto the micropipettes, we have two Eppendorf CellTram Vario pressure pistons, an Eppendorf FemtoJet for ejection of the cells and an engineered hydrostatic force pressure system. For data capture and analysis, we have two Allied Vision Technology cameras, one high speed $(1,600$ fps) and one normal speed (32fps) allowing for general recording and viewing (normal) with simultaneous recording of Brownian motion to detect formation and lifetime of individual bonds (high speed). In addition, we have an Andor iXon EMCCD Camera with sensitivity to a single photon. This is all housed on a Newport Vibration isolation table in a vibration-free room $(\sim 100 \mathrm{sq} f \mathrm{ft})$. Twins screens on the computer allow for real time tracking of bond formation (LabVIEW left screen) and view of the micropipettes (right screen).

\section{Intracellular Cytokine Staining}

Splenocytes isolated from infected mice were plated at 2 $\times 106$ cells per well in a 96-well plate and cytokine production was tested in response to either $41 \mathrm{M}, 41 \mathrm{C}$ or 41CGI peptides. Tested concentrations ranged from $1 \mathrm{uM}$ to. $03 \mathrm{nM}$ in various dilutions. Cells were incubated with peptide for $1 \mathrm{~h}$ at $37^{\circ}$ Celsius in R10 media and washed before Brefeldin A was added (MP Biomedicals) and the cells incubated for another $4 \mathrm{~h}$. R10 media was composed of RPMI 1640 (Mediatech), 10\% heat inactivated FBS (Hyclone), 10 mM HEPES buffer (Mediatech), $2 \mathrm{mM}$ L-glutamine (Mediatech), $50 \mu \mathrm{M} 2$ mercaptoethanol (2ME) (Sigma), and $100 \mu \mathrm{g} / \mathrm{ml}$ gentamicin (Mediatech). Additional samples were also cultured without peptide as a negative control and stimulation with a PMA (20 nM; Fisher Biotech) ionomycin ( $1 \mu \mathrm{M}$; Sigma) combination was used as a positive control. Cells were then washed and stained with surface antibodies in the dark for $30 \mathrm{~min}$ on ice in FACS staining buffer composed of phosphate buffered saline (PBS) (Mediatech), 0.1\% bovine serum albumin (BSA) (Fisher 
Scientific), and $0.05 \%$ sodium azide (Sigma). Surface markers were stained with anti-CD90.2 FITC (53-2.1; Biolegend), antiCD44 PerCP Cy5.5 (IM7; BD), anti-CD3 Brilliant Violet 605 (145.2C11; Biolegend) anti-CD4 Brilliant Violet 711 (RM4-5; Biolegend) and anti-CD8 Brilliant Violet 785 (53.6.7; Biolegend). Using Tonbo bioscience Fix/Perm kit, cells were fixed and permeabilized as per manufacturer's protocol. Intracellular antibody staining with anti-IFN $\gamma$ APC-Cy7 (XMG1.2; BD), antiTNF $\alpha$ PE-Cy7 (MP6-XT22; Biolegend), anti-IL-2 APC (JES65H4; BD), anti-Nur77 PE (12.14; ebioscience) and anti-IRF4 eFluor 450 (3E4; Invitrogen) antibodies was performed as per manufacturers' protocol in a permeabilization buffer for $30 \mathrm{~min}$ on ice. Cells were washed and kept on ice before being run on the LSRFortessa X-20 cell analyzer (Beckton Dickson). All flow cytometry data were analyzed using FlowJo software (Treestar).

\section{Statistics}

Statistical significance of measured values was determined by Ordinary one-way ANOVA and Tukey's multiple comparison test using the Prism Software (GraphPad). Statistical significance indicated as ns $=$ no significance, ${ }^{*} P>0.05,{ }^{*} P>0.01$, ${ }^{* * *} P>0.001$, and ${ }^{* * * *} P>0.0001$.

\section{RESULTS}

\section{Truncation (41C) and Mutation (41M) of Position 41 of the Immunodominant GP33 Epitope (41CGI) Result in Augmented 2D \\ Affinity}

Previous surface plasmon resonance (SPR) 3D affinity data has shown the APL $41 \mathrm{M}$ and $41 \mathrm{C}$ to have similar $3 \mathrm{D}$ affinities, with $\mathrm{K}_{\mathrm{D}}$ values of $17 \mu \mathrm{M}$ and $45 \mu \mathrm{M}$ (50), $9.1 \mu \mathrm{M}$, and $12.2 \mu \mathrm{M}$ (51) and $2.3 \mu \mathrm{M}$ and $3.5 \mu \mathrm{M}$ respectively (52). More recently, the advantages of $2 \mathrm{D}$ based affinity measurements over $3 \mathrm{D}$ SPR analyses have been highlighted using FRET (53) and the mechanical 2D-MP assay $(4,6,22)$. The embedment of the TCR and $\mathrm{pMHC}$ within their respective cell membranes and the use of live cells in such $2 \mathrm{D}$ based analyses give a physiologically relevant portrayal of the TCR's native environment and the $2 \mathrm{D}$ restricted interaction between this receptor and its ligand. Furthermore, 2D affinity correlates closely with the potency of CD4 and CD8 T cells $(6,22,41,44,53-55)$ making 2D-MP a key biophysical parameter. In our experiments, we used the $2 \mathrm{D}$ MP and measured the 2D TCR affinity of LCMV specific naïve TCR-transgenic (P14) CD8 T cells to the three immunodominant GP33 epitopes presented by a mutant $\mathrm{D}^{\mathrm{b}}$ monomer (D227K mutation of the MHC I $\alpha 3$ domain that abolishes CD8 binding) $(6,56-59)$. We found that $41 \mathrm{M}$ had the highest $2 \mathrm{D}$ affinity as compared to wildtype $41 \mathrm{C}$ and $41 \mathrm{CGI}$, with mean population affinities of $1.04 \mathrm{E}-03 \mu \mathrm{m}^{4}, 6.62 \mathrm{E}-04 \mu \mathrm{m}^{4}$, and $1.55 \mathrm{E}-04 \mu \mathrm{m}^{4}$ respectively (Figures 1A). Furthermore, 2D-MP allowed us to take a single T cell of interest and probe against the three pMHCs. The data (Figure 1B) demonstrate the hierarchy of the three GP33 variants occurs at the level of each individual T cell. As a control, the order in which a given pMHC monomer was tested against the same $\mathrm{T}$ cell was randomized. These differences in 2D affinity are independent of any inherent changes in peptide affinity for MHC. Interestingly, while all three pMHC complexes had relatively high $2 \mathrm{D}$ affinities (as compared to $2 \mathrm{D}$ measurements of OT-I with cognate pMHC) (55), 41M had a $\sim 2$-fold higher affinity than $41 \mathrm{C}$ and $\sim 9$-fold higher affinity than 41CGI.

\section{CD8 Contribution to TCR:pMHC Binding Does Not Alter the 2D TCR Affinity Hierarchy to $41 \mathrm{M}, 41 \mathrm{C}$, and 41CGI.}

We next wanted to investigate the contribution of the CD8 coreceptor to the interaction between TCR and the PMHC complex. The affinity of CD8 is significantly lower than the affinity of TCR for pMHC $\left(\mathrm{D}^{\mathrm{b}}\right)(5,46)$ but it is thought to enhance binding to ligands by the lowest affinity TCRs or aid recognition in the presence of low dose antigen (40). One can use wild type pMHC monomers, (intact $\mathrm{D}^{\mathrm{b}}$-CD8 binding) to quantify the number of TCR:pMHC and CD8 to MHC bonds (41). Similar to our TCR:pMHC 2D affinity data, normalized adhesion bonds showed the same trend with $41 \mathrm{M}$ having a bond number higher than $41 \mathrm{C}$ which was higher still than 41CGI (mean bond numbers of $6.40 \mathrm{E}-01,1.01 \mathrm{E}-01$, and $2.93 \mathrm{E}-02 \mu \mathrm{m}^{2}$ respectively) (Figure $2 \mathrm{~A}$ ). Using the same analysis of 2D-MP as in Figure 1B, a single T cell was probed against the three viral variants and the highest to lowest total bond numbers were determined as: $41 \mathrm{M}>41 \mathrm{C}>$ 41CGI (Figure 2B). Additionally, these data demonstrated that the CD8 co-receptor contribution for these relatively high affinity pMHCs was different across the three epitopes (Figure 2A). These data highlighted CD8's ability to contribute differently with each variant epitope, further revealing the differences between $41 \mathrm{M}, 41 \mathrm{C}$, and $41 \mathrm{CGI}$.

\section{CD8 Coreceptor Binding Bolsters Bond Lifetime Under Force but Fails to Restore the 11-Mer 41CGI to a Bond Lifetime Comparable to Either $41 \mathrm{C}$ or $41 \mathrm{M}$}

Previously, using optical tweezer technology, it has been demonstrated that $\mathrm{T}$ cells generate piconewton $(\mathrm{pN})$ force in response to agonist pMHC $(60,61)$. The BFP assay can also be used to apply force to single TCR:pMHC bonds. Under force, the TCR:pMHC interaction can be divided into two types of bonds: bonds that strengthen the interaction between TCR:pMHC as force is applied (a catch bond) or TCR:pMHC interactions that generate a bond that weakens as force increases (a slip bond) $(9,10,61)$.

Here, we apply force to the TCR:pMHC bond with and without the contribution of $\mathrm{CD} 8$ for all three $\mathrm{pMHC}$ variants (Figures 3A-C). In each case, the P14 TCR exhibits a catch bond, which is intensified by the contribution of CD8 (Figure 3C). The bond lifetimes under force also revealed a hierarchy amongst the peptide antigens. In the absence of CD8, 41M had a peak bond lifetime of $\sim 0.8 \mathrm{~s}$ (Figure $3 \mathbf{A}$ ), which was similar to $41 \mathrm{C}$ with a lifetime of $\sim 0.9 \mathrm{~s}$ (Figure $3 \mathbf{A}$ ), both of which were significantly 

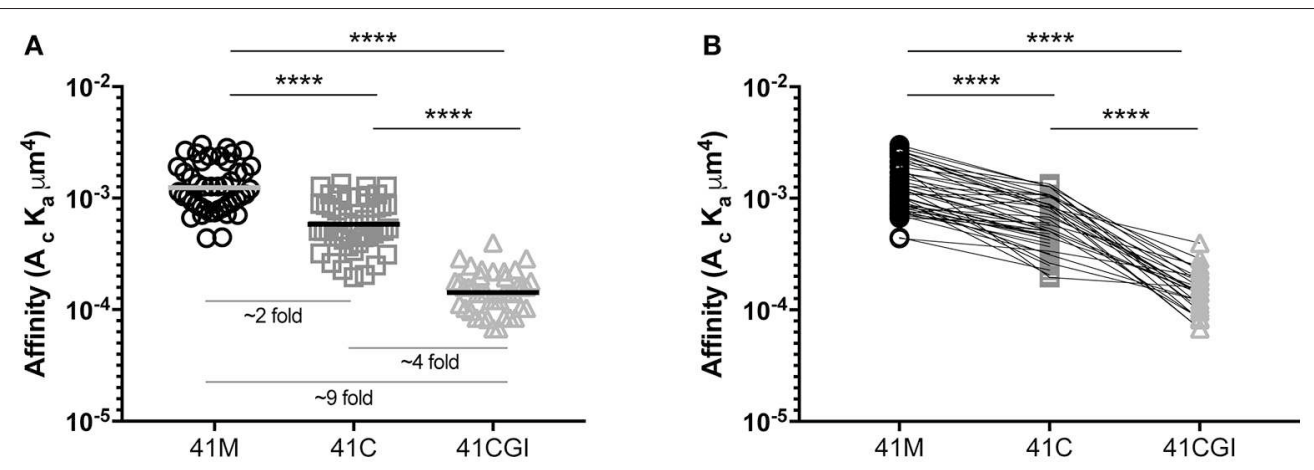

FIGURE 1 | Truncation (41C) and mutation (41M) of position 41 of the naturally processed immunodominant GP33 epitope (41CGI) result in augmented 2D affinity. 2D affinity of naive CD8+ P14 splenocytes tested to either $D^{\mathrm{b}} \mathrm{GP}_{33-41 \mathrm{M}}, \mathrm{D}^{\mathrm{b}} \mathrm{GP}_{33-41 \mathrm{C}}$ or $\mathrm{D}^{\mathrm{b}} \mathrm{GP}_{33-41 \mathrm{CGl}}$ monomers carrying the $\mathrm{D}^{\mathrm{b}} \mathrm{D} 227 \mathrm{~K}$ mutation $(\mathrm{CD} 8-\mathrm{null})$. (A) shows the overall population mean affinity \pm SEM while (B) shows the $2 \mathrm{D}$ affinity of a single P14 CD8+ T cell sequentially tested against each pMHC monomer (test sequence randomized from cell to cell). Statistical significance, ${ }^{\star \star \star \star} P>0.0001$. Ordinary one-way ANOVA Tukey multiple comparison test. Each data point represents the affinity for one $\mathrm{T}$ cell to a given monomer. Data represents 3 individual experiments.
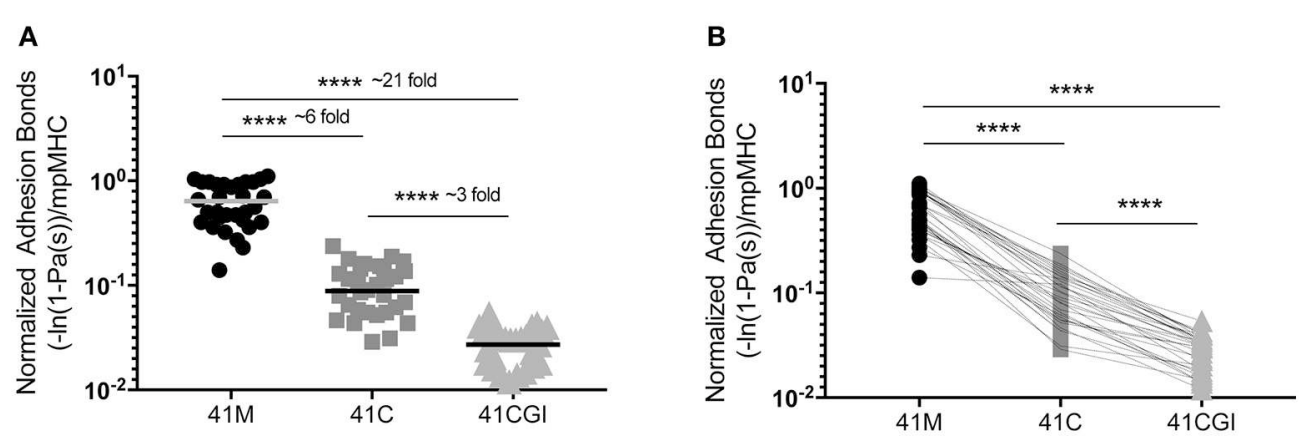

FIGURE 2 | The contribution of CD8 binding to TCR:pMHC does not alter the hierarchy of bond formation between dominant GP33 epitopes. Normalized adhesion bonds for the trimolecular interaction of TCR:pMHC:CD8. (A) Shows the overall normalized adhesion bond mean \pm SEM of cells tested to $41 \mathrm{M}$, $41 \mathrm{C}$ or $41 \mathrm{CGI}$. (B) Shows the individual normalized adhesion bonds of each P14 CD8+ T cell tested to all three pMHC monomers in (A). Statistical significance, ${ }^{\star \star \star \star} P>0.0001$. Ordinary one-way ANOVA Tukey multiple comparison test. Each data point represents the normalized bonds for one T cell to a given monomer. Data represents 3 individual experiments.

higher than 41CGI which had the lowest bond lifetime of $\sim 0.1 \mathrm{~s}$ (Figures 3A,B).

Liu et al. have revealed CD8 coreceptor to be critical for T cell mediated force generation and cell spreading (62). Therefore, we next wanted to investigate the previously uncharacterized CD8 coreceptor contribution to the TCR:pMHC complex under force. Thus, we generated force curves that measured the bond lifetime of TCR bound to CD8-intact pMHC monomers. Our data demonstrated that CD8 contribution significantly increased bond lifetime under force for all three peptide variants, with peak bond lifetimes showing a $\sim 3$-fold increasing from $\sim 0.8$ to $\sim 3.0 \mathrm{~s}$ (Figures 3A,C) for $41 \mathrm{M}$ while $41 \mathrm{C}$ showed a $\sim 2$-fold increase from $\sim 0.9$ to $\sim 1.9 \mathrm{~s}$ (Figures 3A,C). More interesting perhaps was the contribution of CD8 to TCR bond lifetimes under force with 41CGI, which exhibited a $\sim 15$-fold increase from $\sim 0.1$ to $\sim 1.5$ s (Figures 3B,C).

Using the BFP assay, we and others have shown that the bond lifetime of a given TCR:pMHC pair changes when the applied force is varied $(6,9-11)$. Interestingly, we $(10,63)$ and others
$(61,64)$ have also shown that peak bond lifetime is often observed at $\sim 10 \mathrm{pN}$ for both CD4 and CD8 T cells (61). Additionally, Liu et al. have revealed that naïve $\mathrm{T}$ cells can naturally exert 12 $19 \mathrm{pN}$ of force on their TCRs within seconds of ligation (62). Therefore, we highlighted $\sim 10 \mathrm{pN}$ as the physiologically relevant point of comparison of the force curves generated with the three GP33 variant monomers. As such, we found that at $10 \mathrm{pN}$ of force, $41 \mathrm{C}$ has a longer bond lifetime than $41 \mathrm{M}$ and dramatically more so than 41CGI (Figures 3D,E). However, in the presence of CD8, there is no significant difference between $41 \mathrm{M}$ and $41 \mathrm{C}$ (Figures 3F,G). These data highlight the dramatic contribution of CD8 coreceptor toward the weakest variant 41CGI.

\section{D Affinity and Bond Lifetime Under Force Are Indicative of Early T Cell Triggering and T Cell Function}

Next, we determined the effect of the $2 \mathrm{D}$ kinetics on the $\mathrm{T}$ cell response. To assess whether TCR signal from either 

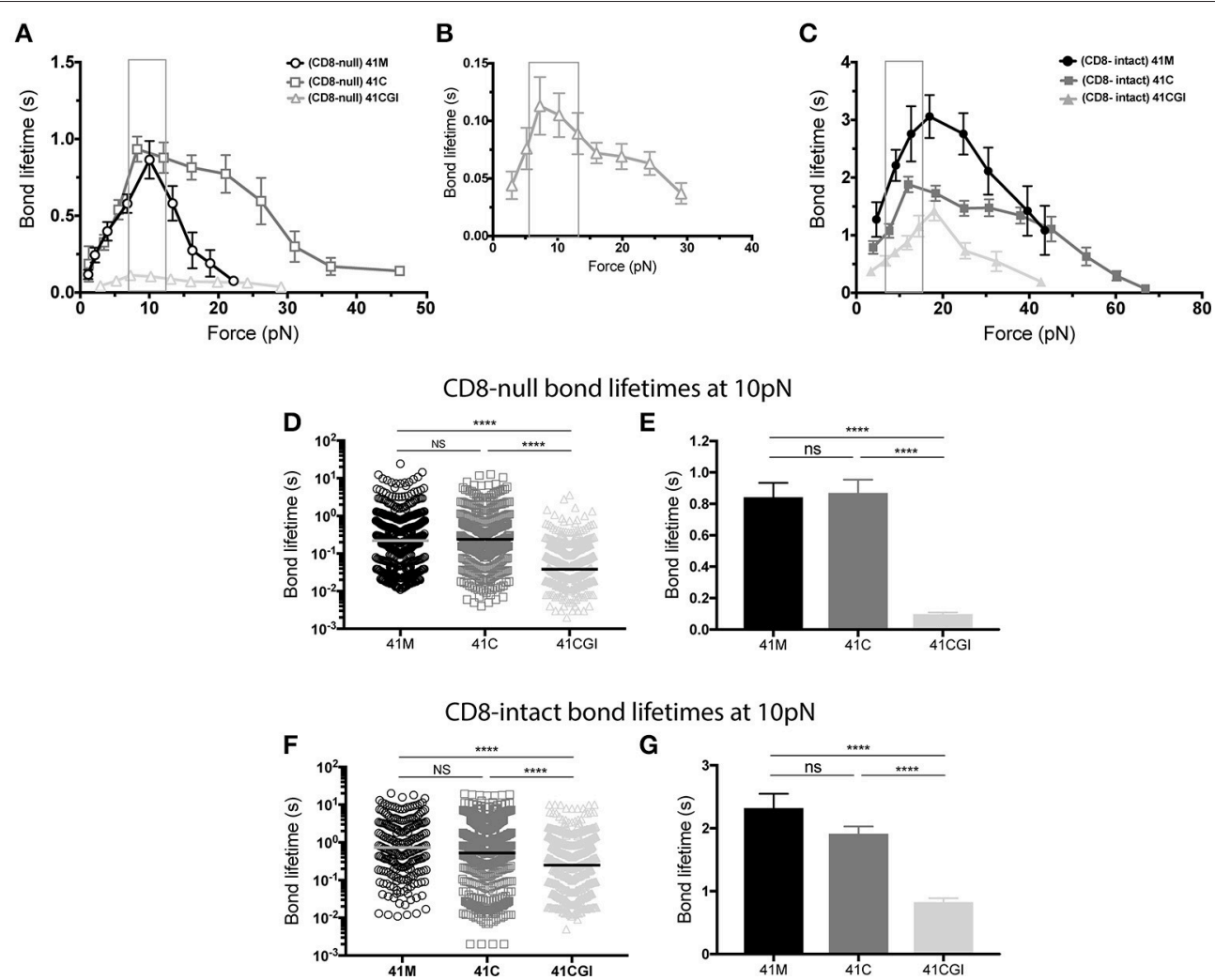

FIGURE 3 | The 11-mer 41CGI has dramatically reduced bond lifetime under force in comparison to $41 \mathrm{C}$ and $41 \mathrm{M}$ even with the contribution of CD8 coreceptor. Bond lifetime under force (A) shows bond lifetime curves for 41M (open circle), 41C (open square) and 41CGI (open triangle) with CD8-null pMHC (B) shows bond lifetime curve for 41CGI with CD8-null pMHC with a smaller scale. (C) Shows bond lifetime curves for 41M (closed circle), 41C (closed square) and 41CGI (closed triangle) with CD8-intact pMHC. CD8-null bond lifetimes at $\sim 10$ pN of force for all three variants shown as (D) a scatter plot or (E) a bar graph. CD8-intact bond lifetimes at $\sim 10 \mathrm{pN}$ of force for all three variants shown as (F) a scatter plot or (G) a bar graph. All force curves generated >1,000 bond lifetimes.

41M, 41C or 41CGI was perceived similarly, transgenic CD8+ P14 T cells were adoptively transferred into congenic hosts (Figure 4A) which were then infected with LCMV Armstrong a day later. Spleens were harvested at peak infection (D8) and cells were re-stimulated ex vivo with each variant peptide. The orphan nuclear hormone receptor, Nur77, has been shown to be rapidly upregulated in $\mathrm{T}$ cells stimulated with antigen via the TCR, but not by inflammatory stimuli (65), and has also been correlated with the strength of the TCR stimulus. Additionally, interferon regulatory factor-4 (IRF4) has been implicated in T cell differentiation and expansion and has been suggested to correlate with the stimulatory potency of a given pMHC (66-68). Our data demonstrated that a higher percentage of CD8 $+\mathrm{T}$ cells restimulated with 41M expressed Nur77 (Figures 4B,E) and have a higher MFI (peaking at $0.31 \mathrm{uM}$ ) than $41 \mathrm{C}$ and dramatically more so than 41CGI (Figures 4C,D,F,G). Similarly, 41C stimulated cells had significantly higher frequencies of Nur77+ CD8+ T cells than those stimulated with 41CGI (Figures 4C,D). However, while there was a difference in IRF4 MFI (Figure $4 \mathbf{H}$ ) between $41 \mathrm{M}, 41 \mathrm{C}$, and 41CGI when cells were stimulated at low peptide doses, we did not observe a difference between 41C and 41CGI at the highest peptide dose tested of $1 \mathrm{uM}$ (Figures 4I,J). These data, while not factoring in peptide loading, indicated that at equivalent peptide doses, ligand potency can correlate with TCR:pMHC 2D affinity $(41 \mathrm{M}>41 \mathrm{C}>41 \mathrm{CGI})$.

Where TCR signal transduction is detectable seconds after TCR engagement with pMHC, cytokine production is observed within hours. Using the same experimental design, we examined cytokine production for the three variants. We show that in response to $41 \mathrm{M}$ (which displayed the highest $2 \mathrm{D}$ affinity and perceived signal strength) cells also produced the most IFN $\gamma$ (Figures 5A,B) and IL-2 (Figure 5D) than either 41C or 41CGI stimulated P14s. However, 41M and 41C activated cells produced similar amounts of TNF (Figures 5C,E). A significantly higher frequency of P14s were also double producers of IFN $\gamma$ and TNF (Figure 5F) and triple producers of IFN $\gamma$, TNF and IL2 (Figure 5G) with $41 \mathrm{M}$ stimulation than post activation with either the $41 \mathrm{C}$ or $41 \mathrm{CGI}$ peptides (Figure $5 \mathbf{H}$ ).

We next wanted to investigate the impact of these peptide variants on the functional response of polyclonal CD8 $+\mathrm{T}$ cells. Thus, we infected C56BL/6 mice with LCMV Armstrong and splenocytes were harvested at peak infection then re-stimulated ex vivo with our peptide variants. Similar to our observation with monoclonal P14 cells, more polyclonal CD8 T cells exhibited increased frequencies of Nur77 expression upon stimulation with $41 \mathrm{M}$ as compared to $41 \mathrm{C}$ and $41 \mathrm{CGI}$ (Figures 6A-D) but 


\section{A}

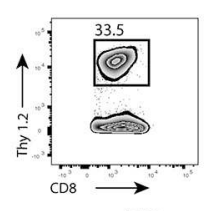

B

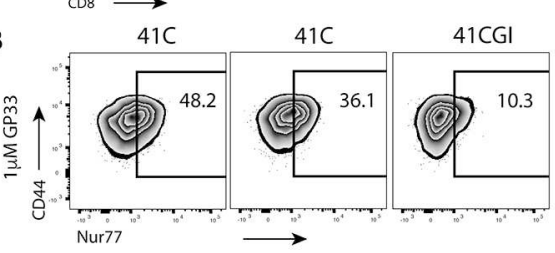

E

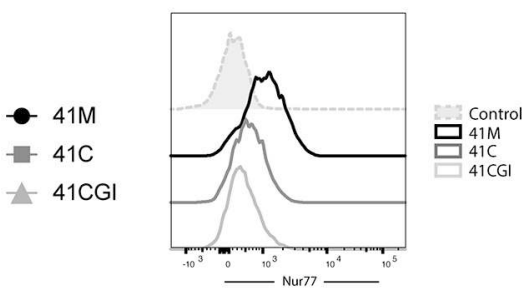

H

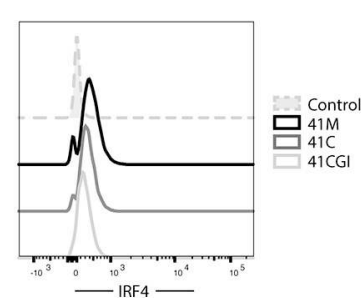

C

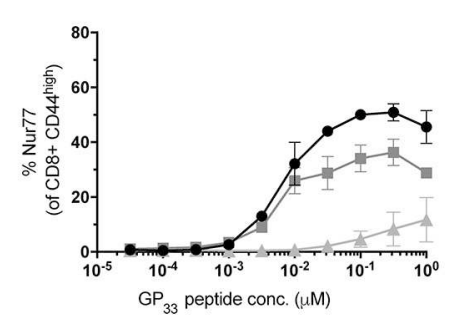

F

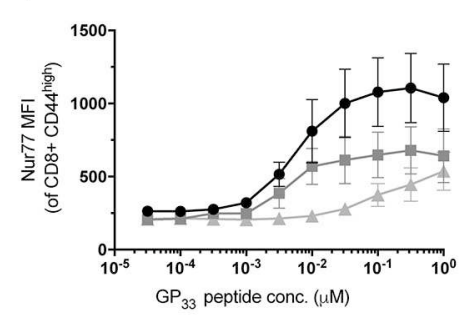

I

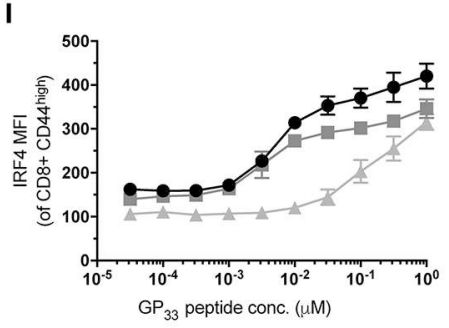

D

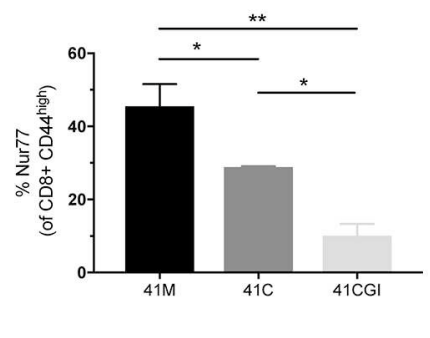

G
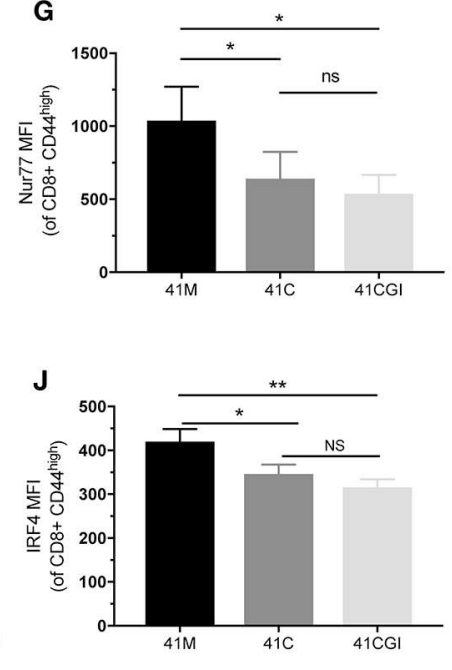

FIGURE 4 | 41M stimulated P14 CD8+ T cells perceive antigen more strongly than either 41C or 41CGI ex vivo. Naïve Thy1.2 P14 CD8+ T cells (1 × 104) were transferred into Thy1.1 congenic B6 hosts that were infected with LCMV Armstrong a day later. Splenocytes were harvested at D8 p.i. and re-stimulated for $1 \mathrm{~h}$ ex vivo with the three peptides at a range of doses (A) Representative contour plot for P14+ Thy1.2 CD8T cell gating strategy. (B) Representative flow cytometry plot gating Nurr77 staining (pre-gated on P14s (CD8+Thy1.2) with 1 uM peptide - left 41M, center 41C and right 41CGI. (C) Shows \%Nur77+ at a range of doses.

(D) Representative Nur77+ staining at 1 uM for each peptide. (E) Nur77 MFI at a range of doses. (F) A representative histogram of Nur77 MFI staining using 1 uM peptide. (G) Shows a representative experiment with Nur77 MFI staining at 1 UM (H) IRF4 MFI at a range of doses. (I) A representative histogram of IRF4 staining using $1 \mathrm{uM}$ peptide. (J) Shows a representative experiment with IRF4 MFI staining at $1 \mathrm{uM}$. Data shown are representative of 3 experiments. $n=3-4$ mice per experiment. Bar graphs with mean \pm SEM. Statistical significance, $\mathrm{ns}=$ no significance, ${ }^{\star} P>0.05,{ }^{\star \star} P>0.01$. Ordinary one-way ANOVA Tukey multiple comparison test.

Nur77 MFI for 41C and 41CGI was not significantly different (Figure 6F). However, IRF4 expression revealed only a slight difference between $41 \mathrm{M}$ and $41 \mathrm{C}$ at the highest peptide dose of $1 \mathrm{uM}$ (Figures 6E-I).

\section{DISCUSSION}

The ability of an antigen specific TCR to be triggered and sufficiently induce activation related changes in the $\mathrm{T}$ cell that lead to clonal expansion and cytokine production is primarily dictated by early interactions with antigen. Identifying how TCR triggering equates to functional outcome and fate is still being investigated. Much of our understanding of TCR affinity for $\mathrm{pMHC}$ and functional outcomes stems from the use of APLs. For the most part, APLs are assumed to be of lower affinity for the TCR based on reduced functional responses. For many APLs exemplified by self and antagonist epitopes, SPR measurements lacked sensitivity to measure binding kinetics.
The OT-I OVA system and its ligands that display high to low functional responses have been used to dissect their direct influence on CD8 T cell effector functions and memory responses (55, 69-71). The 3D affinity for many of the OT-I APLs (71) has not been reported although we have analyzed several for $2 \mathrm{D}$ affinity $(6,55)$. Here, we build on the extensive knowledge of the GP33 immunodominant epitopes, evaluating the correlation between 2D kinetics of affinity and bond lifetime using three variant agonist antigens.

GP33 is documented as being one of the three immunodominant $\mathrm{CD} 8 \mathrm{H} 2-\mathrm{D}^{\mathrm{b}}$ restricted epitopes for LCMV in C57BL/6 mice, along with $\mathrm{GP}_{276-286}$ and $\mathrm{NP}_{396-404}$. Numerous studies have highlighted the contributing factors that confer immunodominance for a given peptide, namely stability of the peptide:MHC I complex, antigen processing and presentation, and TCR:pMHC I binding affinity (72-74). To this background we now overlay the contribution of $2 \mathrm{D}$ affinity and bond lifetime under force. Our data add insight and highlight the importance 


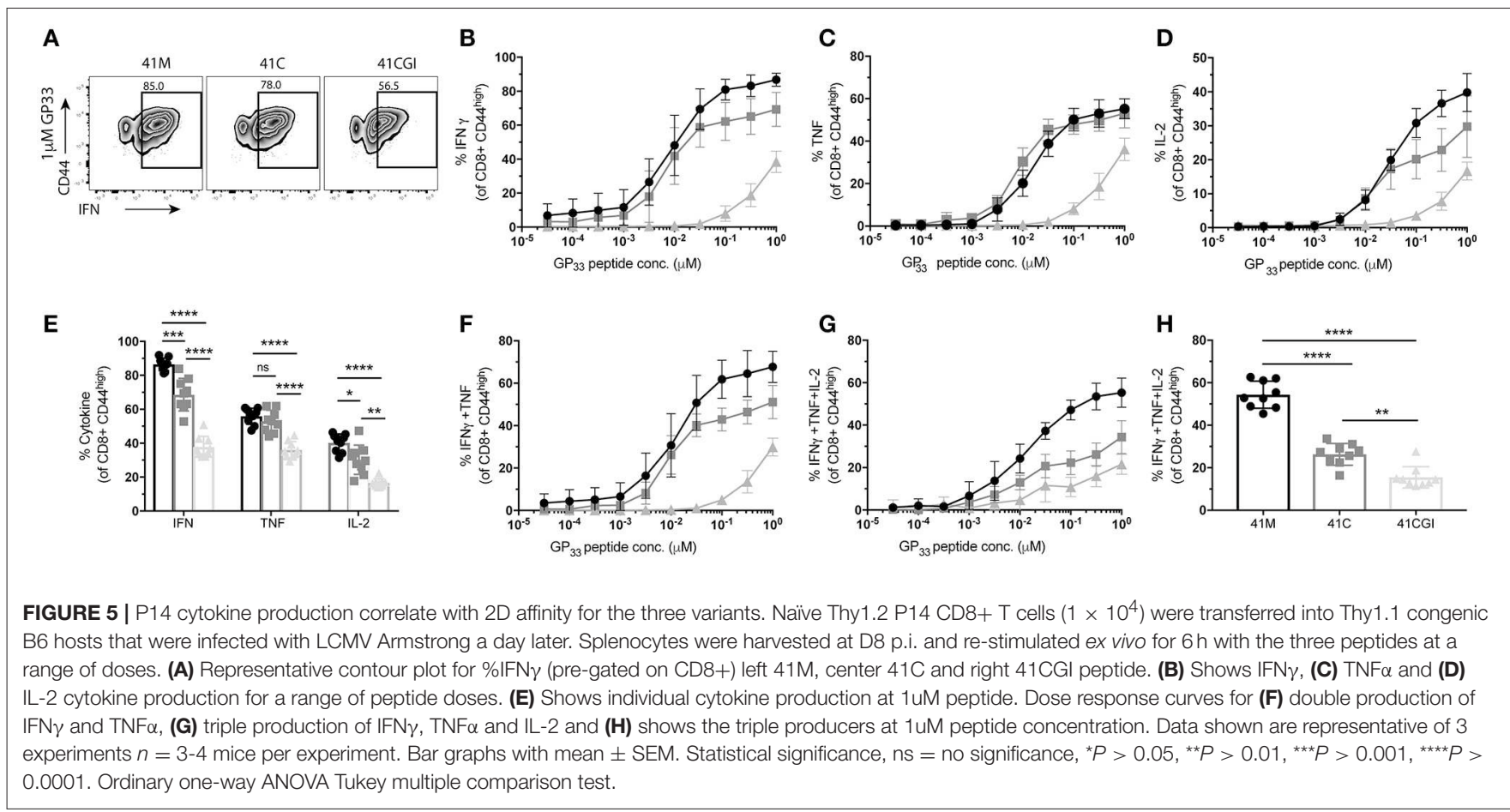

and striking contrast between the most proximal step: TCR 2D affinity for $\mathrm{PMHC}$ and the ensuing TCR bond lifetime for $\mathrm{PMHC}$ under force. Furthermore, we emphasize the capability of 2D-MP to probe single receptor:ligand interactions and resolve subtle but significant changes in peptide binding that are independent of peptide loading.

Gairin et al. demonstrated, based on binding, that the 9-mer (41C) and the 11-mer (41CGI) are the immunodominant GP33 epitopes. In RMA-S MHC stability assays $\left(D^{b} K^{b}\right)$, the 9-mer $41 C$ was six times more efficient than 41CGI at inducing upregulation of $\mathrm{H}-2 \mathrm{D}^{\mathrm{b}}$. However, in competition experiments performed on the $\mathrm{T}-2 \mathrm{D}^{\mathrm{b}}$ cell line, the $11-$ mer $41 \mathrm{CGI}$ was six times more efficient at competing for pMHC than the 9-mer 41C (8). The question is to what extent loading of $\mathrm{MHC}$ affects the $\mathrm{T}$ cell response and their biology. For example, $41 \mathrm{M}$ and $41 \mathrm{C}$ epitopes in our experiments had the same sensitivity to antigen, which would argue similar effective loading. In addition, others have reported biological differences in $\mathrm{T}$ cell responses and migration (interaction with APCs) that $3 \mathrm{D}$ affinity would not explain (51, 52). In the lymph node (LN), $\mathrm{T}$ cell motility has been labeled as having two distinct phases of behavior (36). Phase one type behavior consists of rapid $\mathrm{T}$ cell movements with multiple short sampling encounters with dendritic cells (DCs) before progression to a second phase comprised of stable and long lasting contacts with DCs (75). Henrickson et al. showed T cells interacting with $41 \mathrm{M}$ pulsed DCs transitioned more quickly to phase two than upon encountering 41C. We would suggest that the differences in $2 \mathrm{D}$ kinetics are integral to the different sampling phenotypes with $41 \mathrm{C}$ and $41 \mathrm{M}$. In particular, one could envisage force being important to the biological migration observations to LFA-1 (76).
Several studies have reported the SPR derived 3D affinities for wildtype GP33 (41C) and the 41M mutation with ranges from 2 to $45 \mathrm{uM}$ (50-52). At these levels, there is probably no difference in P14 TCR affinity for 41C or 41M. For example, Boulter et al. show that $41 \mathrm{C}$ and 41CGI have very similar 3D affinities of 2.3 and $3.5 \mathrm{uM}$, respectively. The $2 \mathrm{D}$ measurements displayed at least a 2-fold difference. We have previously identified 2-fold or greater differences in affinity can have profound changes in function $(6,55,77-79)$, which would be consistent with the $41 \mathrm{C}$ giving larger responses as read out by Nur77, IFN $\gamma$ and IL-2. Of note, one cannot directly compare $2 \mathrm{D}$ and $3 \mathrm{D}$ affinities as $3 \mathrm{D}$ affinities are measured in molarity and $2 \mathrm{D}$ affinities are measured in area. Instead, the bond lifetimes could provide a point of comparison. By SPR, $41 \mathrm{C}$ and $41 \mathrm{M}$ show bond lifetimes of $\sim 0.5 \mathrm{~s}$ (51) which is similar to what we find by BFP (0.8-0.9s) for the TCR alone. A major difference in overall force occurs when the effect of CD8 is included as it increases the number of total bonds and the overall catch bond properties. These differences, which likely affect $\mathrm{T}$ cell biology, would not be apparent from the SPR assessment of P14 TCR for the respective GP33 peptides.

The crystal structures of several of the GP33 pMHC complexes have been reported with no major differences that explain our 2D kinetic findings (35). In general analysis of TCR:pMHC, crystal structures have failed to identify obvious factors for catch bond. TCR interactions that cause force are dynamic and occur optimally with CD8, Lck and the cell cytoskeleton (62). In recent collaborative work, it was found that the static crystal structures of pMHC with TCR alone did not identify the type of bond that will be formed under force. However, molecular dynamic simulations (MSD) could be used to add pulling force on the molecules and begin to identify key features (9). 
A

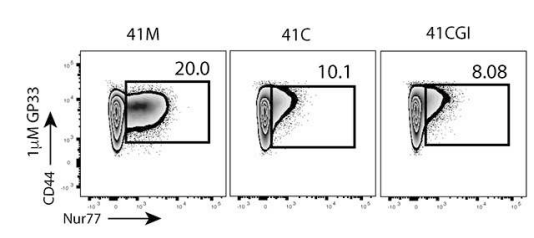

D

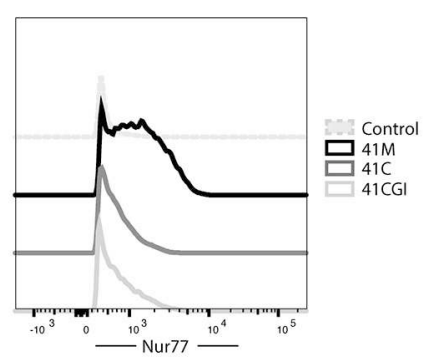

G

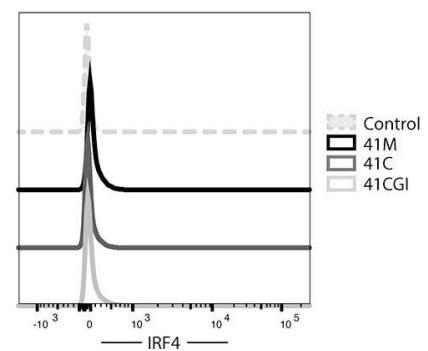

B

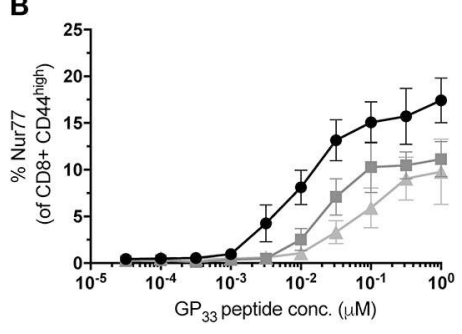

E

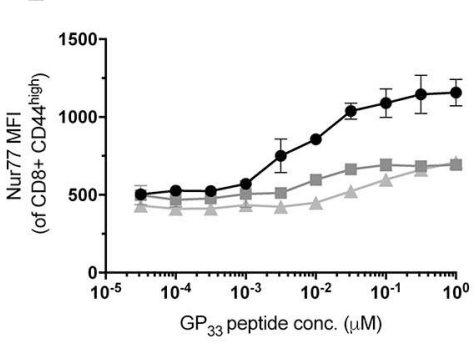

H

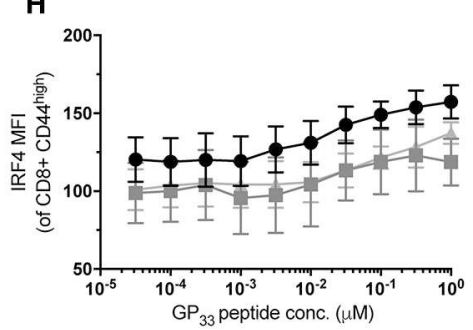

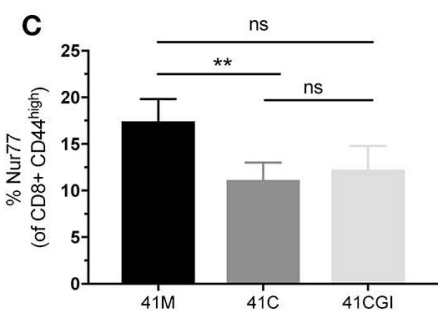

F
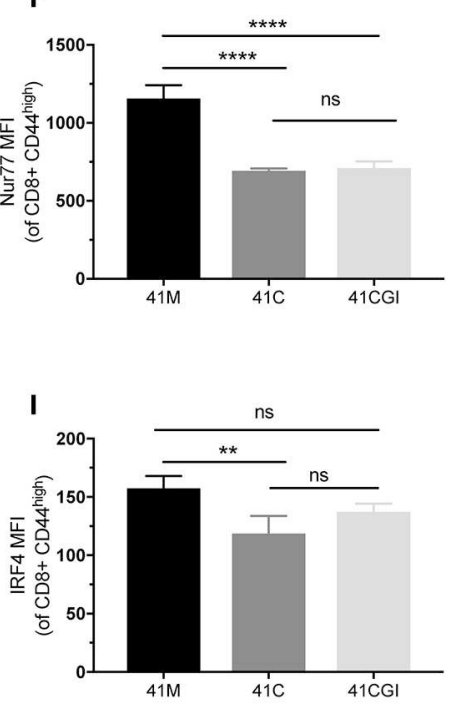

FIGURE 6 | Polyclonal CD8+ T cells recognize 41M more intensely than 41C or 41CGI. B6 mice were infected with LCMV Armstrong and splenocytes harvested at D8 p.i. and re-stimulated with either 41M, 41C or 41CGl ex vivo (A) Representative contour plot for nur77 (pre-gated on CD8+) for left 41M, center 41C, and right 41CGI peptide stimulations. (B) Shows \%Nur77+ at a range of doses. (C) Representative \%Nur77 staining at 1 uM for each peptide. (D) Representative histogram of Nur77 MFI staining at $1 \mathrm{uM}$ for each peptide. (E) Shows Nur77+ MFI at a range of doses. (F) Representative Nur77+ MFI staining at 1 uM for each peptide. (G) A representative histogram of IRF4 staining using $1 \mathrm{uM}$ peptide (H) IRF4+ MFI at a range of doses. (I) Shows a representative experiment with IRF4 MFI staining at 1uM.Data shown are representative of 3 experiments $n=3-4$ mice per experiment. Bar graphs with mean \pm SEM. Statistical significance, ns $=$ no significance, ${ }^{\star \star} P>$ 0.01. Ordinary one-way ANOVA Tukey multiple comparison test.

While 2D kinetics are not impacted by peptide loading as they are single molecule interactions, it is important to note that functional differences might be impacted by peptide loading. However Gairin et al. show that, based on binding, different assays give varying results on whether $41 \mathrm{C}$ or $41 \mathrm{CGI}$ is most stable (8). Our 2D kinetics clearly outline the hierarchy of GP33 epitopes and these data correlate with early signaling events. Using P14 adoptive transfer into congenic hosts studies wherein mice were injected with LCMV Armstrong and then re-stimulated ex vivo with our three peptides, we demonstrated that $41 \mathrm{M}$ stimulated $\mathrm{P} 14 \mathrm{CD} 8 \mathrm{~T}$ cells give a stronger signal than $41 \mathrm{C}$ as measured by Nur77 upregulation. Additionally, both $41 \mathrm{M}$ and $41 \mathrm{C}$ stimulated cells induce significantly stronger signals than 41CGI stimulated cells. While Nur77 is often used as a readout of signal strength and indicative of functionality $(80,81)$, the type of CD8 function cannot clearly be deduced without further analysis. Using the same experimental design, we observed significantly diminished cytokine production in 41CGI stimulated P14 CD8 T cells as compared to $41 \mathrm{M}$ and $41 \mathrm{C}$, and the same hierarchy for P14 CD8 T cells producing IFN $\gamma$ and IL-2 although $41 \mathrm{M}$ and $41 \mathrm{C}$ result in similar amounts of $\mathrm{TNF} \alpha$ at the concentrations used here. Here we show 2D affinity to correlate with triple cytokine production in P14 transgenics. These findings are replicated using polyclonal CD8 $\mathrm{T}$ cells taken from D8 LCMV Armstrong infected mice re-stimulated with the different peptides. The $2 \mathrm{D}$ affinity distribution for a P14 monoclonal population spans a $\sim 10$-fold range while the GP33 specific polyclonal CD8 $\mathrm{T}$ cell population can encompasses a wider $\sim 1,000$-fold affinity range $(82,83)$ but nevertheless the frequency hierarch of triple cytokine producers in response to the three variants is preserved in both despite differences between monoclonal and polyclonal populations and any differences in peptide loading. Moreover, we have demonstrated that using $41 \mathrm{M}$ and its viral escape mutant 35A that while peptide loading is lower with 35A, in a polyclonal LCMV Armstrong infection 2D affinity is not significantly different (84).

Although $\mathrm{T}$ cell responses are aggregations of the TCR bond lifetimes, bond lifetime under force is a single molecule 
measurement independent of peptide loading and is a critical parameter in determining $\mathrm{T}$ cell functionality $(6,10,22)$. While 41CGI had the lowest 2D affinity of the three, it still had a relatively high 2D affinity. Given its high affinity, its low peak bond lifetime of $\sim 0.1 \mathrm{~s}$ was somewhat surprising (Figures $3 \mathbf{A}, \mathbf{B}$ ). We have similarly recently analyzed the HLA B35-HIV epitope and found a high affinity TCR possessing a short bond lifetime that, in this case, showed slip bond characteristics. Together, this demonstrated that affinity and bond lifetime are not always directly correlated (9). Our data show that at $10 \mathrm{pN}$ of force, with or without CD8 contribution there is no significant difference in bond lifetime between $41 \mathrm{M}$ and $41 \mathrm{C}$ suggesting that any difference in functional responses between $41 \mathrm{M}$ and $41 \mathrm{C}$ based from assays in this study could be due to differences in $2 \mathrm{D}$ affinity.

Unlike the OT-I APL system where often the question is how $2 \mathrm{D}$ affinity differences elicit changes in the generation of effector and memory $\mathrm{T}$ cell populations, here the question is how the use of GP33 variants might change the perception of the GP33 epitope immunodominance within the CD8 response to LCMV. Our data clearly show that $41 \mathrm{M}$ elicits higher 2D affinity, increased number of total bonds with CD8 and longer bond lifetime under force as well as a more robust CD8 T cell response than both 41C and 41CGI. Super agonists are ligands for the TCR that stimulate the T cells more than the processed antigenic peptide (85). By our 2D affinity measures and functionality, $41 \mathrm{M}$ would be defined as a super agonist peptide variant as it possesses a prominent difference between 41CGI and the truncated $41 \mathrm{C}$. This raises the question of whether using the super agonist $41 \mathrm{M}$ in lieu of $41 \mathrm{C}$ or $41 \mathrm{CGI}$ gives an accurate

\section{REFERENCES}

1. Zinkernagel RM, Doherty PC. H-2 compatability requirement for T-cellmediated lysis of targe $\mathrm{T}$ cells infected with lymphocytic choriomeningitis virus. Different cytotoxic T-cell specificities are associated with structures coded for in H-2K or H-2D. J Exp Med. (1975) 141:1427-36. doi: 10.1084/jem.141.6.1427

2. Webster AD. Virus infections in primary immunodeficiency. J Clin Pathol. (1994). 47:965-7. doi: 10.1136/jcp.47.11.965

3. Hudrisier D, Oldstone MBA, Gairin JE. The signal sequence of lymphocytic choriomeningitis virus contains an immunodominant cytotoxic T cell epitope that is restricted by both $\mathrm{H}-2 \mathrm{Db}$ and $\mathrm{H}-2 \mathrm{~Kb}$ molecules. Virology (1997) 234:62-73. doi: 10.1006/viro.1997.8627

4. Adams JJ, Narayanan S, Liu B, Birnbaum ME, Kruse AC, Bowerman NA, et al. $\mathrm{T}$ cell receptor signaling is limited by docking geometry to peptide-major histocompatibility complex. Immunity (2011) 35:681-93. doi: 10.1016/j.immuni.2011.09.013

5. Garcia KC, Scott CA, Brunmark A, Carbone FR, Peterson PA, Wilson IA, et al. CD8 enhances formation of stable T-cell receptor/MHC class I molecule complexes. Nature (1996) 384:577-81. doi: 10.1038/384577a0

6. Huang J, Zarnitsyna VI, Liu B, Edwards LJ, Jiang N, Evavold BD, et al. The kinetics of two-dimensional TCR and pMHC interactions determine T-cell responsiveness. Nature (2010) 464:932-6. doi: 10.1038/nature 08944

7. Lim TS, Mortellaro A, Lim CT, Hammerling GJ, Ricciardi-Castagnoli P. Mechanical Interactions between Dendritic Cells and $\mathrm{T}$ cells Correlate with $\mathrm{T}$ cell Responsiveness. J Immunol. (2011) 187:258-65. doi: 10.4049/jimmunol.1100267

8. Gairin JE, Mazarguil H, Hudrisier D, Oldstone MB, Hudrisier D. Optimal lymphocytic choriomeningitis virus sequences restricted by $\mathrm{H}-2 \mathrm{Db}$ major interpretation of the efficacy of the GP33 targeted response relative to the other immunodominant CD8 LCMV epitopes (GP276 and NP396). Furthermore, our data highlight how the CD8 co-receptor engagement with TCR:pMHC can change with viral variants providing another point to consider. Lastly, our work demonstrates the power and sensitivity of $2 \mathrm{D}$ kinetic measurements in demonstrating how TCRs can determine subtle differences in related agonist ligands that can potentially lead to different functional outcomes.

\section{AUTHOR CONTRIBUTIONS}

$\mathrm{EK}$ and $\mathrm{BE}$ conceived the project and wrote the manuscript. $\mathrm{EK}$ and BL performed BFP experiments. EK and RA performed 2D-MP experiments. EK and JJ performed intracellular flow cytometry experiments. EK analyzed all data. BL and RA discussed findings and RA edited the manuscript.

\section{FUNDING}

This work was supported by NIH grant R01 AI096879.

\section{ACKNOWLEDGMENTS}

We thank the National Institute of Health Tetramer Core Facility for providing pMHC reagents and Matthew A. Williams for providing viral stocks. We also thank Catherine Gavile for helpful discussion and Linda Morrison for maintaining mouse colonies.

histocompatibility complex class I molecules and presented to cytotoxic T lymphocytes. J Virol. (1995) 69:2297-305.

9. Sibener LV, Fernandes RA, Kolawole EM, Carbone CB, Liu F, McAffee $\mathrm{D}$, et al. Isolation of a structural mechanism for uncoupling $\mathrm{T}$ cell receptor signaling from peptide-MHC binding. Cell (2018) 174:672-87.e27. doi: 10.1016/j.cell.2018.06.017

10. Liu B, Chen W, Evavold BD, Zhu C. Accumulation of dynamic catch bonds between TCR and agonist peptide-MHC triggers T cell signaling. Cell (2014) 157:357-68. doi: 10.1016/j.cell.2014.02.053

11. Liu B, Chen W, Natarajan K, Li Z, Margulies DH, Zhu C. The cellular environment regulates in situ kinetics of $\mathrm{T}$-cell receptor interaction with peptide major histocompatibility complex. Eur J Immunol. (2015) 45:2099-110. doi: 10.1002/eji.201445358

12. Su X, Ditlev JA, Hui E, Xing W, Banjade S, Okrut J, et al. Phase separation of signaling molecules promotes $\mathrm{T}$ cell receptor signal transduction. Science (2016) 352:595-9. doi: 10.1126/science.aad9964

13. Burroughs NJ, Lazic Z, Van Der Merwe PA. Ligand detection and discrimination by spatial relocalization: A kinase-phosphatase segregation model of TCR activation. Biophys J. (2006) 91:1619-29. doi: 10.1529/biophysj.105.080044

14. Carbone CB, Kern N, Fernandes RA, Hui E, Su X, Garcia KC, et al. In vitro reconstitution of $\mathrm{T}$ cell receptor-mediated segregation of the CD45 phosphatase. Proc Natl Acad Sci USA. (2017) 114:E9338-345. doi: 10.1073/pnas.1710358114

15. Cordoba SP, Choudhuri K, Zhang H, Bridge M, Basat AB, Dustin ML, et al. The large ectodomains of CD45 and CD148 regulate their segregation from and inhibition of ligated T-cell receptor. Blood (2013) 121:4295-302. doi: 10.1182/blood-2012-07-442251

16. George AJT, Stark J, Chan C. Understanding specificity and sensitivity of T-cell recognition. Trends Immunol. (2005) 26:653-9. doi: 10.1016/j.it.2005.09.011 
17. Krogsgaard M, Davis MM. How T cells 'see' antigen. Nat Immunol. (2005) 6:239-45.

18. Germain RN, Stefanová I. The dynamics of T cell receptor signaling: complex orchestration and the key roles of tempo and cooperation. Annu Rev Immunol. (1999) 17:467-522.

19. Jameson SC, Bevan MJ. T cell receptor antagonists and partial agonists. Immunity (1995) 2:1-11. doi: 10.1016/1074-7613(95)90074-8

20. Kersh GJ, Allen PM. Essential flexibility in the T cell recognition of antigen. Nature (1996) 380:495-8.

21. Edwards LJ, Zarnitsyna VI, Hood JD, Evavold BD, Zhu C. Insights into T cell recognition of antigen: significance of two-dimensional kinetic parameters. Front Immunol. (2012) 3:86. doi: 10.3389/fimmu.2012.00086

22. Liu B, Zhong S, Malecek K, Johnson LA, Rosenberg SA, Zhu C, et al. 2D TCRpMHC-CD8 kinetics determines T-cell responses in a self-antigen-specific TCR system. Eur J Immunol. (2014) 44:239-50. doi: 10.1002/eji.201343774

23. Zhong S, Malecek K, Johnson LA, Yu Z, Vega-Saenz de Miera E, Darvishian F, et al. T-cell receptor affinity and avidity defines antitumor response and autoimmunity in T-cell immunotherapy. Proc Natl Acad Sci USA. 110:6973-8. doi: 10.1073/pnas.1221609110

24. Klenerman P, Zinkernagel RM. What can we learn about human immunodeficiency virus infection from a study of lymphocytic choriomeningitis virus? Immunol Rev. (1997) 159:5-16. doi: 10.1111/j.1600-065X.1997.tb01003.x

25. Ahmed R, Salmi A, Butler LD, Chiller JM, Oldstone MBA. Selection of genetic variants of lymphocytic choriomeningitis virus in spleens of persistently infected mice. Role in suppression of cytotoxic $\mathrm{T}$ lymphocyte response and viral persistence. J Exp Med. (1984) 60:521-40. doi: 10.1084/jem.160. 2.521

26. Oldstone MB, Tishon A, Buchmeier MJ. Virus-induced immune complex disease: genetic control of $\mathrm{Clq}$ binding complexes in the circulation of mice persistently infected with lymphocytic choriomeningitis virus. I Immunol. (1983) 130:912-8.

27. Klenerman P, Zinkernagel RM. Original antigenic sin impairs cytotoxic T lymphocyte responses to viruses bearing variant epitopes. Nature (1998) 394:482-5. doi: 10.1038/28860

28. Barber DL, Wherry EJ, Masopust D, Zhu B, Allison JP, Sharpe AH, et al. Restoring function in exhausted CD8 T cells during chronic viral infection. Nature (2006) 439:682-7. doi: 10.1038/nature04444

29. Murali-Krishna K, Altman JD, Suresh M, Sourdive DJD, Zajac AJ, Miller JD, et al. Counting antigen-specific CD8 T cells: a reevaluation of bystander activation during viral infection. Immunity (1998) 8:177-87. doi: 10.1016/S1074-7613(00)80470-7

30. Zajac AJ, Blattman JN, Murali-Krisha K, Sourdive DJD, Suresh M, Altman JD, et al. Viral immune evasion due to persistence of activated $\mathrm{T}$ cells without effector function. J Exp Med. (1998) 188:2205-13. doi: 10.1084/jem.188.12.2205

31. Wherry EJ, Blattman JN, Murali-krishna K, Most R. Van Der, Ahmed R. Viral persistence alters CD8 T-cell immunodominance and tissue distribution and results in distinct stages of functional impairment viral persistence alters CD8 T-cell immunodominance and tissue distribution and results in distinct stages of functional impairment. J Virol. (2003) 77:4911-3927. doi: 10.1128/JVI.77.8.4911-4927.2003

32. Oldstone MB, Lewicki H, Borrow P, Hudrisier D, Gairin JE. Discriminated selection among viral peptides with the appropriate anchor residues: implications for the size of the cytotoxic T-lymphocyte repertoire and control of viral infection. J Virol. (1995) 69:7423-9.

33. Gallimore A, Dumrese T, Hengartner H, Zinkernagel RM, Rammensee HG. Protective immunity does not correlate with the hierarchy of virus-specific cytotoxic T cell responses to naturally processed peptides. J Exp Med. (1998) 187:1647-57.

34. Bachmann M, Speiser D, Ohashi PS. Functional management of an antiviral cytotoxic T-cell response. J Virol. (1997) 71:5764-8.

35. Tissot AC, Ciatto C, Mittl PRE, Grutter MG, Pluckthun A. Viral escape at the molecular level explained by quantitative T-cell receptor/peptide/MHC interactions and the crystal structure of a peptide/MHC complex. J Mol Biol. (2000) 302:873-85 doi: 10.1006/jmbi.2000.4501

36. Henrickson SE, Mempel TR, Mazo IB, Liu B, Artyomov MN, Zheng H, et al. $\mathrm{T}$ cell sensing of antigen dose governs interactive behavior with dendritic cells and sets a threshold for T cell activation. Nat. Immunol. (2008) 9:282-91 doi: $10.1038 /$ ni1559

37. van der Most RG, Murali-krishna K, Whitton JL, Oseroff C, Alexander J, Southwood $\mathrm{S}$, et al. Identification of $\mathrm{Db}$ - and $\mathrm{Kb}$-restricted subdominant cytotoxic T-cell responses in lymphocytic choriomeningitis virus-infected mice. Virology (1998) 240:158-67. doi: 10.1006/viro.1997.8934

38. Renard BV, Romero P, Vivier E, Malissen B, Luescher IF. Participation in TCR - ligand binding. J Exp Med. (1996) 184. doi: 10.1084/jem.184.6.2439

39. Arcaro A, Gregoire C, Bakker TR, Lucia B, Jordon M, Goffin L, et al. CD8beta endows CD8 with efficient coreceptor function by coupling T cell receptor/CD3 to raft-associated CD8/p56(lck) complexes. J Exp Med. (2001) 194:1485-95. doi: 10.1084/jem.194.10.1485

40. Laugel B, van den Berg HA, Gostick E, Cole DK, Wooldridge L, Boulter J, et al. Different $\mathrm{T}$ cell receptor affinity thresholds and CD8 coreceptor dependence govern cytotoxic T lymphocyte activation and tetramer binding properties. J Biol Chem. (2007) 282:23799-810. doi: 10.1074/jbc.M7009 76200

41. Jiang N, Huang J, Edwards LJ, Liu B, Zhang Y, Beal CD, et al. Two-stage cooperative $\mathrm{T}$ cell receptor-peptide major histocompatibility complex-CD8 trimolecular interactions amplify antigen discrimination. Immunity (2011) 34:13-23. doi: 10.1016/j.immuni.2010.12.017

42. Kim C, Jay DC, Williams MA. Stability and function of secondary Th1 memory cells are dependent on the nature of the secondary stimulus. J Immunol. (2012) 189:2348-55 doi: 10.4049/jimmunol.1200244

43. Sabatino JJ, Huang J, Zhu C, Evavold BD. High prevalence of low affinity peptide-MHC II tetramer-negative effectors during polyclonal CD4 ${ }^{+} \mathrm{T}$ cell responses. J Exp Med. (2011) 208:81-90. doi: 10.1084/jem.20101574

44. Andargachew R, Martinez RJ, Elizabeth M, Evavold BD. CD4 T cell affinity diversity is equally maintained during acute and chronic infection. J Immunol. (2018) 201:19-30. doi: 10.4049/jimmunol.1800295

45. Martinez RJ, Andargachew R, Martinez HA, Evavold BD. Low-affinity CD4+ $\mathrm{T}$ cells are major responders in the primary immune response. Nat Commun. (2016) 7:13848. doi: 10.1038/ncomms13848.

46. Huang J, Edwards LJ, Evavold BD, Zhu C. Kinetics of MHC-CD8 interaction at the $\mathrm{T}$ cell membrane. J Immunol. (2007) 179:7653-62. doi: 10.4049/jimmunol.179.11.7653

47. Evans E, Leung A, Heinrich V, Zhu C. Mechanical switching and coupling between two dissociation pathways in a P-selectin adhesion bond. Proc Natl Acad Sci USA. (2004) 101:11281-6. doi: 10.1073/pnas.0401870101

48. Chen Y, Liu B, Ju L, Hong J, Ji Q, Chen W, et al. Fluorescence biomembrane force probe: concurrent quantitation of receptor-ligand kinetics and bindinginduced intracellular signaling on a single cell. J Vis Exp. (2015) 102:27-9. doi: $10.3791 / 52975$

49. Chen W, Evans EA, McEver RP, Zhu C. Monitoring receptor-ligand interactions between surfaces by thermal fluctuations. Biophys J. (2008) 94:694-701 doi: 10.1529/biophysj.107.117895

50. Kerry SE, Buslepp J, Cramer LA, Maile R, Hensley LL, Nielsen AI, et al. Interplay between TCR affinity and necessity of coreceptor ligation: highaffinity peptide-MHC/TCR interaction overcomes lack of CD8 engagement. J. Immunol. (2003) 171:4493-503. doi: 10.4049/jimmunol.171.9.4493

51. Tian S, Maile R, Collins EJ, Frelinger JA. CD8+ T cell Activation is governed by TCR-peptide/MHC affinity, not dissociation rate. J Immunol. (2007) 179:2952-60. doi: 10.4049/jimmunol.179.5.2952

52. Boulter JM, Schmitz N, Sewell AK, Godkin AJ, Bachmann MF, Gallimore AM. Potent $\mathrm{T}$ cell agonism mediated by a very rapid TCR/pMHC interaction. Eur J Immunol. (2007) 37:798-806. doi: 10.1002/eji.200636743

53. Huppa JB, Axmann M, Mortelmaier MA, Lillemeier BF, Newell EW, Brameshuber, et al. TCR-peptide-MHC interactions in situ show accelerated kinetics and increased affinity. Nature (2010) 463:963-7. doi: $10.1038 /$ nature08746

54. Rosenthal KM, Edwards LJ, Sabatino JJ, Hood JD, Wasserman HA, Zhu $\mathrm{C}$, et al. Low 2-dimensional CD4 $\mathrm{T}$ cell receptor affinity for myelin sets in motion delayed response kinetics. PLOS ONE (2012) 7:e32562 doi: 10.1371/journal.pone.0032562

55. Krummey SM, Martinez RJ, Andargachew R, Liu D, Wagener M, Kohlmeier JE, et al. Low-affinity memory CD8 $+\mathrm{T}$ cells mediate robust heterologous immunity. J Immunol. (2016) 196:2838-46. doi: 10.4049/jimmunol. 1500639 
56. Potter T, Bluestone JA, Rajan T. A single amino acid substitution on the alpha3 domain of the H-2 class-I molecule abrogates reactivity with CTL. J Exp Med. (1987) 166:956-66.

57. Potter T, Rajan T, Dick RF, Bluestone JA. Substitution at the 227 of H-2 class-I molecules abrogates recognition by Cd8- dependent, but not CD8independent, cytotoxic T lymphocytes. Nature (1989) 337:73-5.

58. Salter RD, Benjamin RJ, Wesley PK, Buxton SE, Garrett PJ, Clayberger C, et al. A binding site for the T-cell co-receptor CD8 on the alpha 3 domain of HLA-A2. Nature (1990) 345:41-6. doi: 10.1038/345041a0

59. Purbhoo MA, Boulter JM, Price DA, Vuidepot A, Houriga CS, Dunbar PR, et al. The human CD8 coreceptor effects cytotoxic T cell activation and antigen sensitivity primarily by mediating complete phosphorylation of the $\mathrm{T}$ cell receptor $\eta$ chain. J Biol Chem. (2001) 276:32786-92 doi: 10.1074/jbc.M102498200

60. Kim ST, Takeuchi K, Sun ZJ, Touma M, Castro CE, Fahmy A, et al. The $\alpha \beta \mathrm{T}$ cell receptor is an anisotropic mechanosensor. J Biol Chem. (2009) 284:31028-37. doi: 10.1074/jbc.M109.052712

61. Das DK, Feng Y, Mallis RJ, Li X, Keskin DB, Hussey RE, et al. Force-dependent transition in the $\mathrm{T}$-cell receptor $\beta$-subunit allosterically regulates peptide discrimination and pMHC bond lifetime. Proc Natl Acad Sci USA. (2015) 112:1517-22. doi: 10.1073/pnas.1424829112

62. Liu Y, BLanchfield L, Ma VP, Andargachew R, Galior K, Liu Z, et al. DNA-based nanoparticle tension sensors reveal that T-cell receptors transmit defined $\mathrm{pN}$ forces to their antigens for enhanced fidelity. Proc Natl Acad Sci USA. (2016) 113:5610-5. doi: 10.1073/pnas.1600163113

63. Hong J, Persaud SP, Horvath S, Allen PM, Evavold BD, Zhu Z. Force-regulated in situ TCR-peptide-bound MHC class II kinetics determine functions of CD4 + T cells. J Immunol. (2015) 195:3557-64. doi: 10.4049/jimmunol.1501407

64. Feng Y, Brazin KN, Kobayashi E, Mallis RJ, Reinherz EL, Lang M. Mechanosensing drives acuity of $\alpha \beta$ T-cell recognition. Proc Natl Acad Sci USA. (2017) 114:E8204-13 doi: 10.1073/pnas.1703559114

65. Moran AE, Holzapfel KL, Xing Y, Cunningham NR, Maltzman JS, Punt J, et al. $\mathrm{T}$ cell receptor signal strength in $\mathrm{T}$ reg and iNKT cell development demonstrated by a novel fluorescent reporter mouse. J Exp Med. (2011) 208:1279-89. doi: 10.1084/jem.20110308

66. Yao S, Buzo BF, Pham D, Jiang L, Taparowsky EJ, Kaplan $\mathrm{MH}$, et al. Interferon regulatory factor 4 sustains $\mathrm{CD} 8+\mathrm{T}$ cell expansion and effector differentiation. Immunity (2013) 39:833-45. doi: 10.1016/j.immuni.2013.10.007

67. Raczkowski F, Ritter J, Heesch K, Schumacher V, Guralnik A, Hocker L, et al. The transcription factor Interferon Regulatory Factor 4 is required for the generation of protective effector CD8+ T cells. Proc Natl Acad Sci USA. (2013) 110:15019-24. doi: 10.1073/pnas.1309378110

68. Man K, Miasari M, Shi W, Xin A, Henstridge DC, Preston S, et al. The transcription factor IRF4 is essential for TCR affinity-mediated metabolic programming and clonal expansion of T cells. Nat Immunol. (2013) 14:1155-65. doi: 10.1038/ni.2710

69. Knudson KM, Goplen NP, Cunningham CA, Daniels MA, Teixeiro E. Lowaffinity $\mathrm{T}$ cells are programmed to maintain normal primary responses but are impaired in their recall to low-affinity ligands. Cell Rep. (2013) 4:554-65 doi: 10.1016/j.celrep.2013.07.008

70. Daniels MA, Teixeiro E, Gill J, Hausmann B, Roubaty D, Holmberg K, et al. Thymic selection threshold defined by compartmentalization of Ras/MAPK signalling. Nature (2006) 444:724-9. doi: 10.1038/nature05269

71. Zehn D, Lee SY, Bevan MJ. Complete but curtailed T-cell response to very low-affinity antigen. Nature (2009) 458:211-4. doi: 10.1038/nature07657

72. Gallimore A, Hengartner H, Zinkernagel R. Hierarchies of antigenspecific cytotoxic T-cell responses. Immunol Rev. (1998) 164:29-36. doi: 10.1111/j.1600-065X.1998.tb01205.x
73. Yewdell JW, Bennink JR. Immunodominance in major histocompatibility complex class I-restricted T lymphocyte responses 1. Annu. Rev. Immunol. (1999) 17:51-88. doi: 10.1146/annurev.immunol.17.1.51

74. Chen W, Antón LC, Bennink JR, Yewdell JW. Dissecting the multifactorial causes of immunodominance in class I-restricted $\mathrm{T}$ cell responses to viruses. Immunity (2000) 12:83-93.

75. Zheng H, Jin B, Henrickson SE, Perelson AS, von Andrian UH, Chakraborty AK. How antigen quantity and quality determine T-cell decisions in lymphoid tissue. Mol Cell Biol. (2008) 28:4040-51.

76. Jankowska KI, Williamson EK, Roy NH, Blumenthal D, Chandra V, Baumgart $\mathrm{T}$, et al. Integrins modulate $\mathrm{T}$ cell receptor signaling by constraining actin flow at the immunological synapse. Front Immunol. (2018) 9:25. doi: $10.3389 /$ fimmu.2018.00025

77. Merkenschlager J, PloQuin MJ, Eksmond U, Andargachew R, THornborn G, Filby A, et al. Stepwise B-cell-dependent expansion of $\mathrm{T}$ helper clonotypes diversifies the T-cell response. Nat Commun. (2016) 7:10281. doi: $10.1038 /$ ncomms 10281

78. Hood JD, Zarnitsyna VI, Zhu C, Evavold BD. Regulatory and T effector cells have overlapping low to high ranges in TCR affinities for self during demyelinating Disease. J Immunol. (2015) 195:4162-70. doi: 10.4049/jimmunol.1501464

79. Sanecka A, Yoshida N, Kolawole EM, Patel H, Evavold BD, Frickel E. T cell receptor-major histocompatibility complex interaction strength defines trafficking and CD103+ memory status of CD8 T cells in the Brain. Front Immunol. (2018) 9:1290. doi: 10.3389/fimmu.2018.01290

80. Au-Yeung BB, Zikherman J, Mueller JL, Ashouri JF, Matloubian Cheng $\mathrm{DA}$, et al. A sharp T-cell antigen receptor signaling threshold for T-cell proliferation. Proc Natl Acad Sci USA. (2014) 111:E3679-88. doi: $10.1073 /$ pnas.1413726111

81. Feng Y, van der Veeken J, Shugay M, Putintseva EV, Osmanbeyoglu HU, Dikiy S, et al. A mechanism for expansion of regulatory T-cell repertoire and its role in self-tolerance. Nature (2015) 528:132-6. doi: 10.1038/nature 16141

82. Blanchfield JL, Shorter SK, Evavold BD. Monitoring the dynamics of T cell clonal diversity using recombinant peptide:MHC technology. Front Immunol. (2013) 4:170. doi: 10.3389/fimmu.2013.00170

83. Martinez RJ, Evavold BD. Lower affinity $\mathrm{T}$ cells are critical components and active participants of the immune response. Front Immunol. (2015) 6:468. doi: $10.3389 /$ fimmu.2015.00468

84. Shorter SK, Schnell FJ, McMaster SR, Pinelli DF, Andargachew R, Evavold BD. Viral escape mutant epitope maintains TCR affinity for antigen yet curtails CD8 T cell responses. PLoS ONE (2016) 11:e0149582. doi: 10.1371/journal.pone.0149582

85. Degano M, Garcia KC, Apostolopoulos V, Rudolph MG, Teyton L, Wilson IA. A functional hot spot for antigen recognition in a superagonist TCR/MHC complex. Immunity (2000) 12:251-61. doi: 10.1016/S1074-7613(00) 80178-8

Conflict of Interest Statement: The authors declare that the research was conducted in the absence of any commercial or financial relationships that could be construed as a potential conflict of interest.

Copyright (c) 2018 Kolawole, Andargachew, Liu, Jacobs and Evavold. This is an open-access article distributed under the terms of the Creative Commons Attribution License (CC BY). The use, distribution or reproduction in other forums is permitted, provided the original author(s) and the copyright owner(s) are credited and that the original publication in this journal is cited, in accordance with accepted academic practice. No use, distribution or reproduction is permitted which does not comply with these terms. 